FACTA UNIVERSITATIS

Series: Philosophy, Sociology, Psychology and History Vol. 17, No 3, 2018, pp. 179 - 188

https://doi.org/10.22190/FUPSPH1803179T

Review Paper

\title{
PROTESTANTISM - THE ORIGIN AND ESSENCE OF ITS TEACHINGS
}

\author{
UDC 502.1
}

\section{Dragan Todorović}

\author{
University of Niš, Faculty of Philosophy, Niš, Serbia
}

\begin{abstract}
The paper presents the following: 1) The factors which preceded the break of the unique Western Church (spiritual movements within the Roman Catholic Church, which requested a new kind of piety, a New-Century thought by most influential European humanists which was inspired by individualism, a changed political climate under the influence of the Humanism and Renaissance, the rise of the civil class and the invention of the printing press), 2) the founders of Protestant teachings (Martin Luther, Thomas Mincer, Philip Spener, Jean Calvin, Ulrich Zwingli) and 3) the rules of religious life among the newly converted (principles: Ecclesia reformata sed semper reformanda, Soli Deo Gloria, Solo Christo, Sola scriptura, Sola gratia, Sola fide, etc.).
\end{abstract}

Key words: Protestantism, Martin Luther, origin, founders, teaching.

\section{EMERGENCE OF PROTESTANTISM}

In the early sixteenth century in Western Europe, loud appeals were heard for the need for the administrative, legal and moral reformation of the Church. Religious privileges of the rich, immunity of the clergy before the law and their licentious lives, as well as the limitless power of the Pope and abuses in the Church administration were all less and less approved by laymen. At first a return to the origin of the Christian faith was covertly asked within Catholicism itself but the schism was initiated only when the protests were publicly announced by being posted to the door of Wittenberg Castle Church by the German monk of the Augustinian order, Martin Luther (1483-1546):

"Les mauvais moines dont on se moquait, la richesse de l'Église qui pouvait paraître excessive et partiellement inutile, les évêques et les curés qui ne résidaient pas, mais cumulaient les bénéfices, les papes qui se conduisaient en princes séculiers et avaient de ce fait de moins en moins de prise - spirituellement parlant - sur les souverains, l'argent des chrétiens souvent utilisé par Rome à des fins purement terrestres, les excommunications

Received July 30, 2018 / Accepted September 12, 2018

Corresponding author: Dragan Todorović

University of Niš, Faculty of Philosophy, Cirila i Metodija 2, 18000 Niš, Serbia

E-mail: dragan.todorovic@ filfak.ni.ac.rs 
lancées à tort et à travers pour protéger des intérêts parfois bien matériels, tous ces faits contribuèrent à dévaloriser le prêtre et à jeter sur lui, non seulement le discrédit, mais ce qui est plus grave encore, le doute (Delumeau, 2012, 68).'

"The first, though not in the least revolutionary attitudes, Luther built upon since he was more supported than criticized while expressing, later on, an utterly negative attitude toward celibate, fasting, asceticism, Pope's power, ecclesiastical hierarchy, dogmas, external pious deeds and the like thus creating in this way a prerevolutionary climate in which all the classes would find a reason for rebellion in order to realize their interests (Živković 1987, 47)."

Observing the admonitions given by the distinguished world historians, ${ }^{1}$ we think that the break of the communion within the Western Church was decisively contributed to by the following factors:

1. Spiritual movements within the Roman Catholic Church (Waldensians in Switzerland, Lollardy in England, Hussites in Czech) that demanded new devotion (devotio moderna), return to the evangelical ideals of Christian communion and reform of the then ecclesiastical life reduced to the popular worship of a multitude of saints and relics as well as trivial forms of religiosity.

2. New Age thought of the most influential European humanists inspired by individualism (Desideris Erasmus Roterodamus /1466-1536/ - "the Voltaire of the sixteenth century")

3. A changed political climate under the influence of Humanism and Renaissance (Machiavellian ideal of the secular state, due to the interference of the Vatican into the national affairs of the then monarchies, appointment of church officials and tax collection).

4. Rising middle class (restrictions upon the economically strengthened trade and craft layers and nobility as imposed by the framework of the feudal rule and economy),

5. Invention of the press or the Internet of the past times (transmission of religious ideas and printing of the tracts and the Bible in vernacular).

The beginning of the Reformation was taken to be October 31, 1517 when Doctor and Professor of Theology at the University of Wittenberg, Martin Luther, presented for dispute his 95 theses on absolutions, dogmas and establishment of the Catholic Church. The papal bull Exsurge Domine ("Arise, O Lord"), which threatened him with excommunication, he cast into the fire before the Elstergate of Wittenberg; he defiantly responded with three writings important for the Christians intent on splitting from the Roman hierarchy (To the Christian Nobility of the German Nation, On the Babylonian Captivity of the Church and On the Freedom of a Christian). After being excommunicated from the Church, on the Diet of Worms in the same year, he stated that he would not recant his teaching giving a response "without horns and without teeth":

\footnotetext{
1 "Cependant, il est indéniable que des circonstances nombreuses et diverses - économiques, sociales, géographiques jouèrent un rôle, délicat au reste à mesurer, dans le passage au protestantisme de telle région ou de tel groupe social. On peut rêver de dresser, pour chaque cas territorial ou sociologique, le catalogue des circonstances qui, agissant comme des catalyseurs, favorisèrent le glissement vers la Réforme” (Delumeau, 2012, 17).
} 
"Unless I am convicted by scripture and plain reason--I do not accept the authority of popes and councils for they have contradicted each other--my conscience is captive to the Word of God. I cannot and I will not recant anything, for to go against conscience is neither right nor safe. Here I stand, I cannot do otherwise, God help me. Amen. (quoted from Léonard 2002,73).”

Therefore, his refusal to recant his beliefs at the demand of People Leo X in 1520 and the Holy Roman Emperor Charles V in Worms in 1521 resulted in his excommunication by the Pope and condemnation as an outlaw by the Holy Roman Emperor Charles V. He was now forced to hide under the protection of Frederick the Wise, Elector of Saxony, at the Wartburg Castle at Eisenach. This officially marked separation of Lutherans and Catholics. During his stay at Wartburg he was devoted to the first translation of the New Testament from Greek into German. He came back to Wittenberg in 1522 and supported the first uprisings of the German peasants in 1525; yet, he later strongly opposed rebelliousness and cruelly punished the rebels in the Protestant areas. At the 1530 Imperial Diet of Augsburg the central documents of Lutheranism were presented, based on the year earlier published Luther's Small Catechism. It was as early as 1532 that the first translation of the Old Testament from Hebrew to German appeared.

On the left Lutheran wing new radical Protestants appeared - Anabaptists (Hutterites, Melchiorites, Mennonites) whose leaders were at the head of numerous peasants' rebellions. The movement is supposed to have represented "a natural reaction of a Protestantism of choice (protestantisme de choix) against mass Protestantism" (Léonard 2002: 180). Thomas Müntzer radically rejected the practices of the Catholic Church and asked from his adult followers another baptism (lat. Anabaptism - re-baptism) and separation from the world. Luther was against it and wrote a severe dispute against Anabaptists as well as those against papacy and Jews. ${ }^{2}$ Though mostly peaceful, the movement members were severely prosecuted throughout Europe by both Lutherans and Catholics; in fighting for their own lives, they reached Russia, Canada and America.

Disappointed with feuds in the Protestant world, and having suffered seriously damaged health for a few years, Luther died on February 18, 1546 in Eisleben, the city of his birth. He was succeeded by Philipp Melanchthon (1497-1560), also known as the creator of the Augsburg Confession (Confessio Augustana, 1530), the official primary confession of faith of the Lutheran Church. In the year of 1555, at the Peace of Augsburg, the proclamation of religious peace and equality of Protestants to freely opt for their religious choice on their own territory was witnessed (cuius regio, eius religio).

Philipp Jakob Spener, 1635-1705, in his work Pia desideria (1675), presented, in 1675, the principles of a new movement - Pietism; it implied the study of the Bible, personal religious experience, better theological education, missionary activities of the believers, high ethical standards and the like. In the later phases of the movement development, it established connections with English Puritans, Dutch Precisionism and French Quietism (Enciklopedija živih religija 2004, 544).

\footnotetext{
${ }^{2}$ His anti-Jewish theses fostered the formation of the anti-Semitic German Evangelical Church in the days of Nazism. It advocated for singularly racist attitudes while presenting itself as the church of the Aryan race (sr.wikipedia.org/wiki/Мapmuн_Лymep).
} 
Lutheranism gained footing in Germany, Scandinavia and North Europe while in Switzerland, France, Scotland and Holland a new form of the non-Lutheran reform started to emerge, namely Calvinism, mainly under the influence of a Frenchman from Geneva, Jean Calvin (1509-1564) and Swiss leader Hulderich Zwingli (1484-1531).

Jean Calvin, together with Martin Luther, was the most important person of the Protestant Reformation. Jean Delumeau (1998, 137) notices how Calvin - at the moment when Luther's Reform, in the mid-sixteenth century, had already begun losing force, due to the founder's death, numerous military defeats and doctrinaire concessions to Catholicism "il a renouvelé la vie and la puissance de la Réforme." Three years after sudden conversion (Subita conversio), Calvin, in Basel, in 1536, published the first edition of the Institutes of the Christian Religion in which he discussed the issue of the relationship between God and man just as he gave his interpretation of the Ten Commandments (Calvin 1996, 10). He reorganized the Church in many aspects (organizationally, disciplinarily and dogmatically) introducing four church services; i.e., his church had four officers: pastors, teachers, elders, and deacons. Pastors were to preach and administer the sacraments, doctors or teachers to instruct believers in the proper observance of the faith while deacons were to care for the poor and sick. Elders, that is, presbyters, were responsible for discipline and morality in the Church thus establishing the Presbyterian system of rule (Kolarić 1976, 51-2).

Calvinism is based on the belief in predestination, that is, the belief that man's fate is determined by an all-powerful and ungraspable God's will. The duty of each man is to consider himself chosen, to believe that he is predetermined for the salvation of his soul while the most crucial means of dispelling religious doubts and lifting up confidence in the certainty of mercy is tireless vocational work. In the Protestant teaching, work has a fundamental theological meaning of salvation, unlike its role as a means of existential self-preservation in the Catholic doctrine. On "a short pilgrimage of life", religious ideas about the importance of commitment to the accomplishment of the God-given secular tasks orders the behavior of believers:

"...and there remains, more and more strongly emphasized, the statement that the fulfillment of worldly duties is under all circumstances the only way to live acceptably to God. It and it alone is the will of God, and hence every legitimate calling has exactly the same worth in the sight of God" (Weber 2005, 41).

“...man, as a supervisor of his own activities, gets exhausted in the production of material goods which are not ends in themselves but their amassment is a consequence of an inner need of man to express himself, through creation, as a true believer who, by leading an exemplary Christian life, serves God by increasing his glory and power" (Živković 1983,77-8).

Diligent work devoted to God, prayer, life in keeping with the desire to increase one's fortune along with self-restraint in its spending - these are all assumptions of the future successful linkage of individualism in the religious domain with the economic individualism of the impending "first Industrial Revolution" (Weber 1997). Taking as a whole the entire history of the West, Protestantism

\footnotetext{
"par sa théologie, par ses déviations postérieures - on pense ici au puritanisme -, par certaines de ses conséquences pratiques, a certainement aidé l'homme moderne à sortir du Moyen Âge et de la mentalité précapitaliste. Il a été un ferment qui a qui a accéléré l'épanouissement d'un monde radicalement différent de celui qu'avaient connu Auguste, Charlemagne et Innocent III (Delumeau, 2012, 360).”
} 
Ulrich Zwingli (1484-1531), a pastor from Zürich, was a leader of the Reformation in Switzerland and the first reformed theologian. He was after a more radical reform than Luther: Christians are obliged to do what the Bible teaches them and do nothing beyond what is written. For Zwingli, the Reformation had a social and national character thus acknowledging the right of the secular power to deal with ecclesiastical issues; yet, in 1529 he debated Luther in Marburg on the interpretation of the essence of the Eucharist, holding that Christ in the Eucharist is present only spiritually or symbolically. For his adamant beliefs he paid with his life in the Battle of Kappel in 1531, while defending Zürich from the Swiss Roman Catholic cantons. His teachings are summarized in the Second Helvetic Confession (Confessio helvetica) that was later taken up by the reformed congregations of Poland and Hungary as well. In Zürich the Reformation movement was later led by Johann Heinrich Bullinger (1504-1575) while in Geneva by Theodore Beza (1519-1605).

Under Calvin's influence, the Reformation ideas penetrated France as early as 1555 , thus gradually outgrowing into a political movement (Huguenots). Massacred in 1572 on the eve of the St. Bartholomew's Day, the reformers were then protected in 1589 by Henry IV, a Huguenot before converting to Roman Catholicism, who protected and recognized them through the Edict of Nantes in 1598.

The Reformation came to Holland in 1523, but the first Reformation Synod was held in Dort in 1574; it endorsed Heidelberg Catechism. Arminius (1560-1609) opposed the widely accepted Calvinist explanation of the nature of predestination by claiming that God wants all people to be saved and not only the chosen ones. Though condemned at the Synod of Dort (1618-1619), Arminius's teaching was acknowledged in 1795.

In 1534, King Henry VIII appointed himself the Supreme Head of the Church of England thus rejecting the authority of Pope Clement VII (1523-1534) who had, in 1532, annulled his divorce from Catherine of Aragon. The Archbishop of Canterbury Thomas Cranmer (1489-1556) introduced the Reformation in England on the wave of the protest movements of an evangelical character under the leadership of John Wycliffe (1328?1384) and wrote and compiled the first two editions of the Book of Common Prayer and the Thirty-nine Articles, an Anglican statement of faith. He was condemned as a heretic by the Roman Catholic Mary I Tudor who attempted to re-introduce papal authority in England. Queen Elisabeth I accepted the spirit of the Reformation while preserving, at the same time, the basic structures of Catholicism such as episcopate and liturgy. In 1563 the Anglican doctrine was accepted in the form of the Thirty-nine Articles. The most deserving for the spread of the Reformation in Scotland is John Knox (1505?-1572) who, in 1561, compiled The Book of Discipline. The Scottish Church accepted the Presbyterian system of rule thus advancing the spread of Presbyterianism to the "New Continent."

The Puritan ethic and spirituality, in the late sixteenth and early seventeenth century, among the English Protestants represented a new wind in the sails of the Reformation requests for the purity of religious life: every Christian has to undergo his own experience of conversion and only true converts can become members of the Church. They made a lasting impact on the colonies of New England as well as on the entire later American Protestantism; a famous example is the Great Awakening, 1740-1750, under the leadership of great North American theologian Jonathan Edwards. 
In the Czech Republic the influence of Lutherans was waning after 1524, while the Hussites mainly turned into Calvinists, and while Hungary was under the equal influence of both: a synod at Erdőd in 1545 was Lutheran, while a later synod in Debrecen in 1567 accepted the Reformed Heidelberg Catechism along with the Second Helvetica Confession which more closely followed the teachings of Jean Calvin. The Scandinavian countries were reached by the Reformation in 1527; the Synod of Uppsala embraced the Augsburg Confession. In Denmark and Norway the first Protestant congregations were organized in 1536.

The Roman Catholic Church responded with the Counter-Reformation. Pope Paul III initiated the Council of Trent (held in three sessions, 1545-1547, 1551-1552 and 15621563). The basic Catholic tenets denied by Luther were explained and strengthened scholastically: salvation through faith and works of that faith, seven sacraments, celibacy, purgatory, absolutions, transubstantiation and the papal authority (Delimo 1993, 81-108). In order to reinforce the effects of the Counter-Reformation, the Roman Catholic Church supported the foundation of the Jesuit order (The Society of Jesus) under the leadership of Ignacio de Loyola, (1491-1556); it organized the Congregation of the Holy Office of the Inquisition (better known as "Inquisition) and compiled the Index of Forbidden Books (Index Librorum Prohibitorum) of theologically erroneous or immoral books.

"Because of the Roman Catholic opposition encountered, Protestant expansion in Eastern Europe was far from smooth. The Catholic Counter-Reformation weakened Protestantism in many Central-Eastern European countries. Except for some minor remnants, the CounterReformation almost wiped out Protestantism in Slovenia and Croatia and certainly paralysed Protestant development in Poland. Similar histories occur in Hungary and in Bohemia and Moravia, where up to 90 per cent of the population were Protestant by the end of the sixteenth century, but this was dramatically, permanently and rapidly reversed. As a result, in present day Hungary a quarter of the population belongs to Protestant churches (primarily Lutheran and Reformed) while the majority population is Roman Catholic. Today approximately 40 per cent of Czechs are Roman Catholic and only 10 per cent belong to non-Catholic denominations (Hussite, Evangelical Church of the Czech Brethren, and others). In Poland and Lithuania, only a very small minority of the population is Protestant (Parushev and Pilli 2004, 156-57)."

The resolutions of the Council of Trent added tension to the otherwise strained relations between "brother-enemies" - the Roman Curia and Protestants - that led do the Thirty Years' War (1618-1648). Finally, by the Peace of Westphalia in 1648 Lutherans gained the same rights as Roman Catholics. In 1680 the Book of Concord was published including two of Martin Luther's Catechisms, his Smalcald Articles, The Augsburg Confession and The Apology of the Augsburg Confession by Philipp Melanchthon and The Formula of Concord. ${ }^{3}$

Today Protestantism is prevailing in North and Middle Europe, the United States, Canada, part of South America and Africa as well as Australia. ${ }^{4}$

\footnotetext{
${ }^{3}$ A brief survey of the origin, expansion and achievements of Protestantism in Western Europe can be found in Boisset, 1985.

${ }^{4}$ For a detailed survey of Protestantism in the Balkans and Serbia see: Bjelajac 2003, 2010; Kuzmič 2007; Marinović Bobinac and Marinović Jerolimov 2008; Todorovic 2011.
} 


\section{The EsSENCE OF PROTESTANT TEACHINGS}

The notion of "Protestantism" is related to the protest of six princes and representatives of fourteen imperial cities expressed at the Diet of Speyer or Speyer II in the imperial City of Speyer in 1529. They protested against rescindment of the provisions of the Diet of Speyer in 1526 (or Speyer I) that promised legal security to the reformed countries as well as religious liberty to individuals. Their response to the issue of man's attitude to God in everyday life was imbued with the Biblical belief that man has to subject himself to God rather than people. The interpretation of the Biblical word and its teaching, as well as the conscience of individuals and their personal responsibility before God became the pattern of Protestant life in former Europe.

The term Protestantism in general denotes a set of different churches that founded their teachings upon the doctrines of the $16^{\text {th }}$ century Protestant reformers, that is, Evangelical (Lutheran) and Reformed (Presbyterian or Calvinist) Churches. The term is also used for the Anglican Church that separated from Rome in 1543 for the political and personal reasons of King Henry VIII while, after his death, it accepted Protestantism mostly in the Calvinist model (Episcopalians led by Samuel Senbury represent its separate branch in America). Later separations were those of Presbyterians (founder John Knox in Scotland in 1560), Congregationalists (founder Robert Brown from Holland, 1582), Baptists (founder John Smith in Amsterdam, 1606), Quakers (founder George Fox, 1650), Methodists (founder John Wesley in England, 1774), Mormons (or the Church of Jesus Christ of Latter-day Saints) founder Joseph Smith in Palmyra, New York, 1829), Adventists (founder William Miller, 1863), Pentecostals (Charles Fox Parham from Kansas, 1901), Jehovah's Witnesses (founder Charles Taze Russel, 1879; under this name since 1931) as well as other numerous churches of various names and teachings. However, those originating from the Reformation, are not rarely spoken of as "the churches of the Reformation legacy" or "free churches of the radical Reformation tradition."

"The churches of the Reformation legacy, separate and independent, accepted, from Luther's Protestantism, only that Scripture, grace and faith are the foundations of man's relationship with God, while, from the radical wing of the Reformation, they inherited teaching about scholarship, the belief that man must believe first before receiving the blessings of baptism, an awareness about the practical reading of Christ's mission in the Gospel's Annunciation as well as ardor for evangelization." (Jambrek 2007, 92).

What it comes to is a whole specter of non-Roman Catholic Western Christianity with a variety of doctrines. ${ }^{5}$

\footnotetext{
${ }^{5}$ The most frequent ambiguity that we come across in the referential literature in Serbian is the use of two slightly different adjectives, evangelički and evanđeoski, with the Lutheran Churches usually denoted as evangeličke while the Pentecostal as evanđeoske. Evangelical Lutheran churches are authentic Protestant churches while Evangelical Pentecostal churches rest upon the radical wing of the Reformation. The adjective as used in the latter stresses the central role of Jesus Christ, grace, faith and Scripture in the beliefs and activities of the church (Jambrek 2003, 18.9). The very term "evangelical" comes from the Greek in which the New Testament was written; more precisely, it comes from the Greek word euangelion, meaning "the good news" or the "gospel" (Bjelajac 2007, 13).
} 
The discovery at the core of the Reformation is that every man is justified before God only due to the grace and free will of God. It is also important to emphasize the Reformation conception of clergy of all believers, which represented "the Copernican turn" for the times in which it was created. From the special service of clergy to general clergy, from the hierarchical understanding of the church to the participatory one, from subordination and superiority of communities to equality among brothers and sisters these are new rules of religious life among the reformed.

The dogmas of this new, "awakened" faith are considered to be:

1. The principle ecclesia reformata, semper reformanda (the church reformed, always reforming),

2. Soli Deo Gloria (Glory to God Alone), life dedicated to God existing through three divine figures, the Father, Son and the Holy Spirit,

3. Solo Christo (Christ alone) - teaching about Christ as the only head of the church (contrary to the Catholic teaching that the Pope is the "vicar of Christ" and that he takes Christ's place as the visible head of the church which gives him the right to speak ex cathedra, that is with the authority of infallibility when it comes to the issues of faith and practice),

4. Sola Scriptura (By Scripture Alone) - the Bible is the final authority on issues of faith and church activity (unlike the Roman Catholic teaching that the Bible and the tradition are sources and norms of faith, equal and parallel, while the tradition is the only legitimate and infallible interpreter of the Bible),

5. Sola gratia (By Grace Alone) - absolute submission to God's free, unmerited favor as a means of salvation or salvation by grace alone (salvation is not within the range of man's responsibility but it is an unalterable plan of God who acts freely in history),

6. Sola fide (By Faith Alone) justification by faith and not good works (evangelical blessing is given to the repentant believer by the Power of the Holy Spirit, that is, by preaching words; good works are neither a condition for justification nor addition to the faith but fruits, proofs of justification),

7. "The priesthood of all believers," that is, "priests and equality of all believers" and the right to free exploration of the Gospel unlike the former church hierarchy (pastors and preachers differ from other Christians only by function and appointment, not by spiritual status),

8. Teaching about the church as a communion of saints, that is, a communion of newborns, Christians baptized in maturity,

9. Teaching about separateness and independence of each local community,

10. Concept of scholarship including evangelization, ethics and social activities,

11. Simplicity of religious service with an emphasis on sermons and prayers; acceptance of only two Sacraments: baptism and the Eucharist (called the Lord's Supper),

12. Repudiation of idolatry, saint worship and various forms of popular worship,

13. Sanctity of all professions and vocations,

14. Allowing clergy to marry and believers to divorce, and,

15. Agape - love as a motive of Christian life. 


\section{REFERENCES}

Асенов, Бончо. 2002. Религиите и сектите в България (второ преработено и допълнено издание). София: Бончо Станоев Асенов.

Бјелајац, Бранко. 2003. Протестантизам у Србији (Прилози за историју реформацијског наслеђа у Србији - I део). Београд: Алфа и Омега.

Бјелајац, Бранко. 2007. Еванћеоско хришћанство: основне одлике. Београд: Иконос.

Бјелајац, Бранко. 2010. Протестантизам у Србији (Прилози за историју реформацијског наслеђа у Србији -II део). Београд: Сотериа.

Boisset, Jean. 1985. Kratka povijest protestantizma. Zagreb: Kršćanska sadašnjost.

Breuilly, Elizabeth, Joanne O’Brien, and Martin Palmer, eds. 2005 [1997]. Religions of the World. New York: Facts on File, Inc.

Weber, Max. 1989. Protestantska etika i duh kapitalizma. Sarajevo: "Veselin Masleša" i "Svjetlost".

Вебер, Макс. 1997. Сабрани списи о сочиологији религије, I. Сремски Карловци и Нови Сад: Издавачка књижарница Зорана Стојановића.

Weber, Max. 2005. The Protestant Ethic and the Spirit of Capitalism. London and New York: Routledge.

Делимо, Жан. 1993. Католицизам између Лутера и Волтера. Сремски Карловци, Нови Сад и Цетиње: Издавачка књижарница Зорана Стојановића и Издавачки центар „Цетиње“.

Delumeau Jean, Thierry Wanegffelen, and Bernard Cottret. 2012. Naissance et affirmation de la Réforme. Paris: Presses Universitaires de France, URL: https://www.cairn.info/naissance-et-affirmation-de-la-reforme-9782130584056.htm

Драгојловић, Драгољуб. 2009а. Богомилство на Балкану и у Малој Азији, 2. Београд: Службеник гласник. - 2009б. Крстјани и јеретичка ирква босанска. Београд: Службеник гласник.

Enciklopedija živih religija (2. fototipsko, dopunjeno izdanje). 2004. Beograd: Nolit.

Etches, Stephen. Pregled povijesti crkve. Krapina: UTBP, 2005.

Živković, Jovan. 1983. Marksistička kritika protestantskgo shvatanja rada. Magistarska teza, Fakultet političkih nauka Univerziteta u Beogradu.

Живковић, Јован. 1987. „Опште карактеристике протестантског покрета.“ Марксистичке теме 11 (3-4): 45-54.

Jambrek, Stanko. 2003. Crkve reformacijske baštine u Hrvatskoj. Zagreb: Bogoslovni institut.

Jambrek, Stanko. 2007. „Pentekostni pokret u Hrvatskoj 1907-2007.“ Kairos I (2): 235-60.

Kalvin, Žan. 1996. Nauk hrišćanske vere. Sremski Karlovci i Novi Sad: Izdavačka knjižarnica Zorana Stojanovića.

Kolarić, Juraj. 1976. Kršćani na drugi način. Zagreb: Veritas.

Kuzmič, Franc. 2007. „Pregled povijesti pentekostnog pokreta u Jugoslaviji od početka do 1991.“ Kairos I (2): 221-34.

Leonar, Emil Ž. 2002. Opšta istorija protestantizma, I i II. Zagreb, Sremski Karlovci i Novi Sad: Jesenski i Turk i Izdavačka knjižarnica Zorana Stojanovića.

Marinović-Bobinac, Ankica i Marinović-Jerolimov, Dinka. 2008. Vjerske zajednice u Hrvatskoj (Kratka povjest, vjerovanja, obredi, hijerarhija, organizacija, članstvo, tradicija, običaji $i$ blagdani). Zagreb: Udruga za vjersku slobodu u RH i Prometej.

Milić, Jasmin i Ivan Balta. 2005. „Povijesni razvoj protestantizma s posebnim osvrtom na kalvinizam u Slavoniji.“ Život $i$ škola 14 (2): 46-60.

Parushev, Parush, and Toivo Pilli. 2004. Protestantism in Eastern Europe to the Present Day. In The Blackwell Companion to Protestantism, edited by Alister E. McGrath and Darren C. Marks, 155-60. Oxford: Blackwell Publishing.

Стоянов, Маньо. 1964. „Начало на протестантската пропаганда в България.“ В Известия на Института за история, том 14-15, 45-67. София: Българска Академия на науките.

Тодоровић, Драган. 2011. „Протестантизам на Балкану и у Србији“. Социолошки преглед 45(3):265-294.

Ćutić-Gorup, Maja. 2009. „Dekret nadvojvode Ferdinanda iz 1599. o izgonu protestanata.“ Croatica Christiana Periodica 33 (63): 77-85. 


\section{PROTESTANTIZAM - NASTANAK I SUŠTINA UČENJA}

U radu se predstavljaju: 1. činioci koji su prethodili razbijanju jedinstvene zapadne crkve (duhovni pokreti unutar Rimokatoličke crkve koji su zahtevali novu pobožnost, novovekovna misao najuticajnijih evropskih humanista inspirisana individualizmom, promenjena politička klima pod uticajem humanizma $i$ renesanse, građanska klasa u usopnu $i$ uspon štampe), 2. osnivači protestantskog učenja (Martin Luter, Tomas Mincer, Filip Špener, Žan Kalvin, Urlih Cvingli) $i 3$. pravila verskog života među reformisanima (načela: Ecclesia reformata sed semper reformanda, Soli Deo Gloria, Solo Christo, Sola scriptura, Sola gratia, Sola fide i dr.).

Ključne reči: protestantizam, Martin Luter, nastanak, osnivači, učenje. 